\title{
Effect of Thermo-Chemical Pretreatment of Kenyan Market Waste on Mesophillic Biogas Production
}

\author{
Kamau J. M*, Mbui D. N, Mwaniki J. M, Waswa G. A.
}

Department of Chemistry, University of Nairobi, P.O. Box 30197-00100, Nairobi, Kenya

*Corresponding author's E-mail address: djames085@gmail.com

Article Info

Volume 8, Issue 3

Page Number: 22-31

Publication Issue :

May-June-2021

\section{Article History}

Accepted : 05 May 2021

Published: 10 May 2021

\section{ABSTRACT}

Effects of pretreatment on the anaerobic digestion of waste fruit and vegetable market waste were investigated in biogas production by batch experiments. The pretreatment was $\mathrm{NaOH}$ and $\mathrm{HCl}$ thermochemical, thermal and chemical methods. The wastes were chopped and blended before loading to the digester. Acid hydrolysis was done by adding $20 \mathrm{ml} 0.1 \mathrm{M} \mathrm{HCl}$ with thorough mixing before purging with $\mathrm{CO}_{2}$ and sealing. Alkaline pretreatment was done using $1 \mathrm{M} \mathrm{NaOH}$. In both cases, the setups were exposed to heat at $100^{\circ} \mathrm{C}$ for 12 hours, after which they were allowed to cool for 3 hours. The $\mathrm{pH}$ was modified to $6.7-7.2$ before loading the inoculum and studying biogas generation. The large-scale setups with 1.01, 1.5l, $5 \mathrm{l}$ and 101 capacity were studied for biogas generation.

The results obtained show that thermochemical pretreatment results in more cumulative biogas production at $6200 \mathrm{ml}$, followed by thermal at $4900 \mathrm{ml}$ and then chemical pretreatments at $3750 \mathrm{ml}$ for $500 \mathrm{~g}$ mixed fruits and vegetable market wastes. Alkaline pretreatment is more efficient compared to acidic hydrolysis though highly influenced by proximate properties of the wastes and operation $\mathrm{pH}$. The large-scale pretreatment resulted in $34500 \mathrm{ml}$ and $31400 \mathrm{ml}$ cumulative biogas from $\mathrm{HCl}$ and $\mathrm{NaOH}$ pretreatment.

In conclusion, thermochemical pretreatment of market waste results in increased biogas generation resulting from hemicellulose breakdown and disrupting ligninhemicellulose ether bonds in acid hydrolysis. In contrast, alkaline pretreatment leads to swelling of lignocelluloses and partial lignin solubilization lignin breakdown. The overall biogas generation depends on proximate waste matter and digester operation $\mathrm{pH}$.

Keywords : Biogas, Market waste, Thermo-chemical, Pretreatment

\section{INTRODUCTION}

The main merit of the market waste substrate is its availability. However, anaerobic digestion of these wastes faces competition from livestock feeding or composting. In biogas generation, the plant waste substrate tends to accumulate lignin and other indigestible materials that must be regularly removed

Copyright: (C) the author(s), publisher and licensee Technoscience Academy. This is an open-access article distributed under the terms of the Creative Commons Attribution Non-Commercial License, which permits unrestricted non-commercial use, distribution, and reproduction in any medium, provided the original work is properly cited 
from digesters. This severely limits the use of plant wastes in continuous-feeding digesters (Anderson, 1972). Pretreatments have the potential to improve A.D. systems considerably. Their implementation must still be guided by the specific substrate's actual improvement potential and valued in their particular context for process design and framework conditions (Carlsson et al., 2012). The time taken to degrade a substrate to biogas depend on the carbohydrate bonds (Noike et al., 1985).

Like sugars like glucose, simple molecules are processed into biogas by microorganisms in anaerobic digestion (Günther and Lucy, 2013).

There are two types of chemical pretreatments; Alkali pretreatment and acid hydrolysis. The building blocks and content of lignocellulosic matter make them resistant to hydrolysis. Alkali addition causes swelling of lignocellulose (Kong et al., 1992) and partial lignin solubilization. Lime and sodium $\mathrm{NaOH}$ is the most commonly employed alkalis in feedstock pretreatment. Several studies have been published that alkali treatment is beneficial for A.D. In batch tests using rice straw pretreated with 6 percent solid $\mathrm{NaOH}$ for three weeks at ambient temperature, He et al. (2008) showed a substantial increase in biogas yield. Liew et al. (2011) performed simultaneous solid-state pretreatment and methanization on fallen leaves using 3.5\% $\mathrm{NaOH}$ and showed that the methane yield increased by 20 percent during batch tests. Substrates pretreatment with alkaline solutions lead to salt build-up and increased $\mathrm{pH}$ during continuous fermentation and $\mathrm{pH}$ balancing. The high salt concentration and the effect on the ammoniumammonia balance inhibit methanization (Chen et al., 2008). Beccari et al. (2001) demonstrated that $\mathrm{pH}$ rise favours low $\mathrm{pH}$ and high lipid content substrates. High costs of chemicals make the pretreatment technology economically unattractive (Chang et al., 1997). Acid hydrolysis pretreatment does not interfere with lignin, but is believed to function by breaking down hemicellulose and disrupting the ether bonds of lignin-hemicellulose (Knappert et al., 1981). Typically, acidic hydrolysis is combined with heat.

In thermochemical pretreatment, the influence of heat and chemical is combined. Various acids and bases have been employed though ammonia, and other solvents usage has been used. The employed temperatures range from 60 to $220^{\circ} \mathrm{C}$. Methane generation decreased at temperatures ranging between $160-200^{\circ} \mathrm{C}$, subject to the substrate composition (DiStefano and Ambulkar 2006; Penaud et al., 1999; Delge 'nes et al., 2000). Heating of substrate during alkaline pretreatment of sludge results in an increase in C.O.D. solubilization (100\%) and a higher gas yield (20\%) in comparison to alkali pretreatment (Kim et al., 2003). In a study by Zhang et al. (2011), the influence of acidic (1.32-4.68\% $(\mathrm{w} / \mathrm{w}))$ pretreatment and heat $\left(150-170^{\circ} \mathrm{C}\right)$ on cassava substrate was investigated. They recorded a $57 \%$ gas yield increase compared to untreated cassava. Maximum biogas production was recorded at $160^{\circ} \mathrm{C}, 3 \%$ $\mathrm{H}_{2} \mathrm{SO}_{4}$ and 20 minutes' hydraulic retention time(H.R.T.) (Zhang et al., 2011). In this study, the influence of thermochemical, thermal, and chemical pretreatment of market wastes using alkaline and acidic media was investigated and its influence on biogas production at mesophilic conditions.

\section{Methodology}

\section{Substrate and inoculum}

Fresh solid vegetable and fruits market wastes(F.V.M.W.); Cabbage (Brassica oleracea capittta), Coriander (Coriandrum sativum.),Papaya (Carica papaya), Spinach (Spinacia oleracea), Kales (Brassica oleracea acephala), Pumpkin Leaves (Cucurbita maxima), Kahurura (Cucumis ficifolia), Pig Weed (Amaranthus spp.), African Nightshade (Solanum nigrum),Mango (Mangifera indica), Togotia (Erucastrum arabicum), comfrey (Symphytun 
officinale), Banana (Musa spp), Sweet Potato (Ipomoea batatas), Cucumber(Cucumis sativus), Watermelon (Citrullus lanatus), Tomato (Lycopersicon lycopersicum), Potato (Solanum tuberosum), Avocado (Persea americana), and Courgette (Cucurbita pepo) were obtained from Kangemi/Wakulima market in Nairobi County. The F.V.M.W. were subjected to size reduction using a knife before being homogenized using a blender. The inoculum used was obtained from a running digester composing of cow dung.

\section{Waste analysis}

The wastes were analyzed for proximate matter and the physicochemical properties as described in Kamau et al., 2020.

\section{Thermo-Chemical Pretreatment}

The waste was blended to increase pretreatment surface area. After loading into a $250 \mathrm{ml}$ glass bottle, it was subjected to thermal, chemical and thermochemical pretreatment before biogas production at psychrophilic conditions. Further studies were carried out at thermo-chemical pretreated wastes.

\section{Alkali pretreatment}

Each waste was cut into small pieces before blending using a kitchen blender. The waste $(200 \mathrm{~g})$ was then placed in a glass bottle, and $20 \mathrm{ml} 1 \mathrm{M} \mathrm{NaOH}$ was added. The mixture was thoroughly shaken before purging and sealing. The set up was then placed in a water bath and maintained at $55^{\circ} \mathrm{C}$ for 24 hours, after which it was removed and allowed to stabilize for 6 hours. The inoculum was added, and the biogas generation was studied at $25^{\circ} \mathrm{C}$ for ten days. The same was done with the waste mixture(F.V.M.W.) for thermal and chemical pretreatment.

\section{Acid hydrolysis}

The market waste was then mixed with 0.1M H.C.L. $(\mathrm{pH} 1)$ and pre-hydrolysis allowed for 24-48 hours at
37-40 degrees with stirring. After the pretreatment step, the waste was loaded to the digester and $\mathrm{pH}$ adjusted to $6.8-7.2$ using $\mathrm{NaOH}$. The inoculum was added, and the mixture was purged with $\mathrm{CO}_{2}$ to create an anaerobic environment before sealing. Cumulative biogas produced at mesophilic conditions was monitored for ten days. The setup is shown in figure 1.

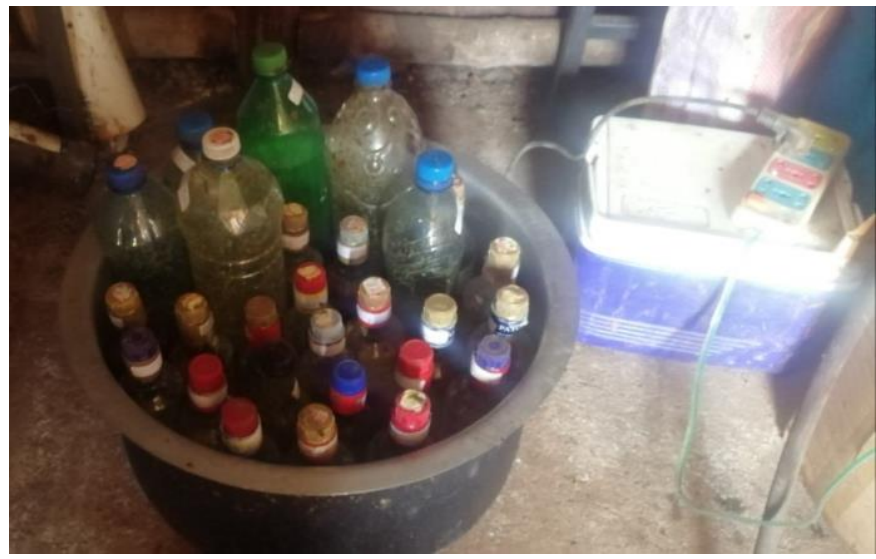

Figure 1: A setup of F.V.M.W. pretreatment process

\section{Large-scale waste pretreatment}

The above procedures were repeated using 1.0, 1.5, 5 and 10 litres' digesters loaded with mixed market wastes. The setup was removed from the water bath and allowed to stabilize for 6 hours before adjusting the $\mathrm{pH}$ to 6.8-7.2. The inoculum was then added and mixed thoroughly. Cumulative biogas generation was studied for 17 days' retention time. The setup is shown in figure 2.

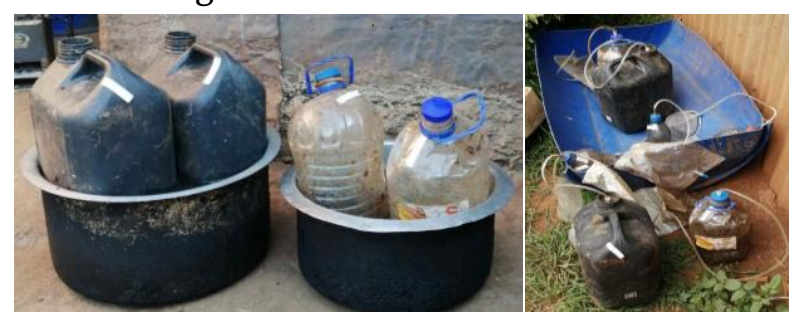

Figure 2 : Large-scale biogas production from pretreated market wastes

\section{RESULTS AND DISCUSSION}

The proximate analysis involves analyzing crude proteins, fibre, fat, carbohydrates, moisture, ash, nitrogen-free extract and Energy. Table 1 shows the 
proximate properties of various fruit waste from Nairobi County. Table 2 shows the physical properties of the market wastes on a dry and fresh weights basis. These properties influence the pretreatment process. For example, Peces et al. (2015) demonstrated that substrate moisture (total solid concentration) is a significant parameter for pretreatment performance. However, it has been rarely considered in pretreatment optimization. Specifically, moisture optimization increased the methane yield of brewer's spent grain by $6 \%$ for low-temperature pretreatment $\left(60^{\circ} \mathrm{C}\right)$ and $14 \%$ for ultrasound pretreatment $\left(1000 \mathrm{kJkgTS}^{-1}\right)$. However, a study by Chen, Ke and Liang (2019) reported no significant difference in methane production for the three moisture contents studied during pretreatment $(54 \%, 70 \%$, and $77 \%)$ of the rose stalk.

Different waste pretreatment results in different biogas generation levels for similar wastes. In thermal pretreatment setups, the highest cumulative biogas obtained was $2384 \mathrm{ml}, 4126 \mathrm{ml}$ and $5207 \mathrm{ml}$ for $500 \mathrm{ml}$, 1 liter and 1.5liters digesters, respectively, compared to $2297 \mathrm{ml} 3139 \mathrm{ml}$ and $4127 \mathrm{ml}$ in chemical pretreatment for similar digesters. The highest cumulative biogas was reported in the thermochemical methods at $3579 \mathrm{ml}, 4888 \mathrm{ml}$ and $6160 \mathrm{ml}$ for $500 \mathrm{ml}$, 1liter and 1.5liters digesters, respectively, as shown in figure 3 .

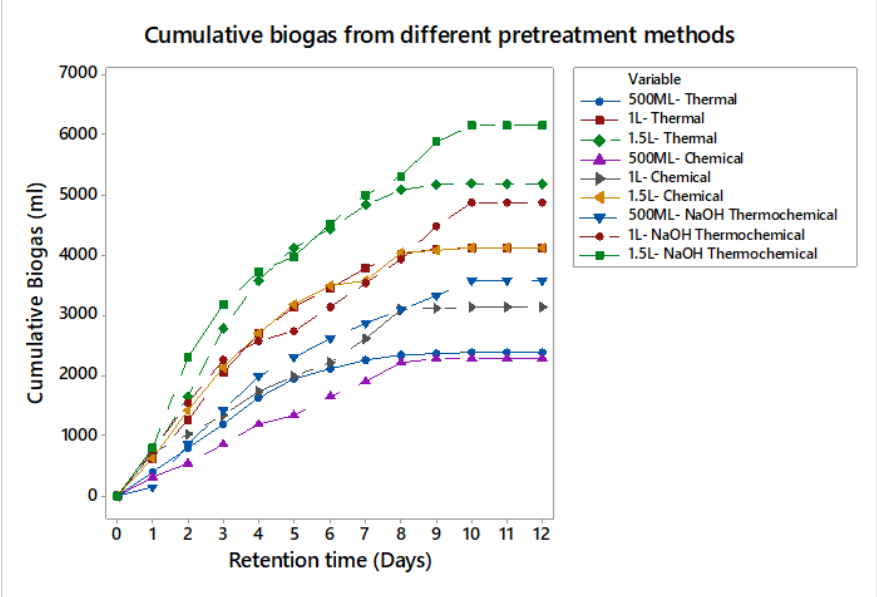

Figure 3 : Cumulative biogas produced from F.V.M.W. with varying pretreatment methods
In thermal treatment, the substrate building blocks are disintegrated by heat, thereby increasing the substrate surface area. In figure 4, acidic hydrolysis and alkaline pretreatment thermochemical methods were compared. Higher cumulative biogas production was evident in $\mathrm{NaOH}$ digesters compared to $\mathrm{HCl}$ hydrolysis at $2909 \mathrm{ml}, 422 \mathrm{ml}$ and $5137 \mathrm{ml}$ in $500 \mathrm{ml}$, 1liter, and 1.5liter $\mathrm{HCl}$ pretreated digesters, respectively compared to $3579 \mathrm{ml}, 4888 \mathrm{ml}$ and $6160 \mathrm{ml}$ $\mathrm{NaOH}$ waste pretreated, respectively. The acetate groups are separated from hemicellulose in alkali pretreatment, rendering the hemicellulose more available to hydrolytic enzymes. It strengthens digestibility. The addition of alkali also induces lignocellulose swelling, which is a secondary influence (Kong et al., 1992). This causes swelling, leading to an increase in internal surface area, decrease in the degree of polymerization, decrease in crystallinity, separation of structural linkages between lignin and carbohydrates, thus increasing the cellulose hydrolysis (Kleinert, 2008). Alkali pretreatment appears to be a more efficient choice for pretreatment purposes (Damisa, Ameh \& Umoh, 2008). Mancini et al. 2018 employed different chemicals in the pretreatment of wheat straws, the organic solvent $\mathrm{N}$-methylmorpholine $\mathrm{N}$-oxide (N.M.M.O.) at $120 \mathrm{C}$ for $3 \mathrm{~h}$, ii) the organosol method, employing ethanol as the organic solvent at $180 \mathrm{C}$ for one hour and iii) using an alkaline pretreatment with $\mathrm{NaOH}$ at $30 \mathrm{C}$ for $24 \mathrm{~h}$. The study observed that the cumulative bio-methane production yield of $274 \mathrm{~mL}$ $\mathrm{CH} 4 / \mathrm{g}$ VS obtained with the untreated feedstock was enhanced by $11 \%$ by the N.M.M.O. pretreatment $15 \%$ by both the organo-solvent and alkaline pretreatment depending on the different impact on the chemical composition of the straw. 


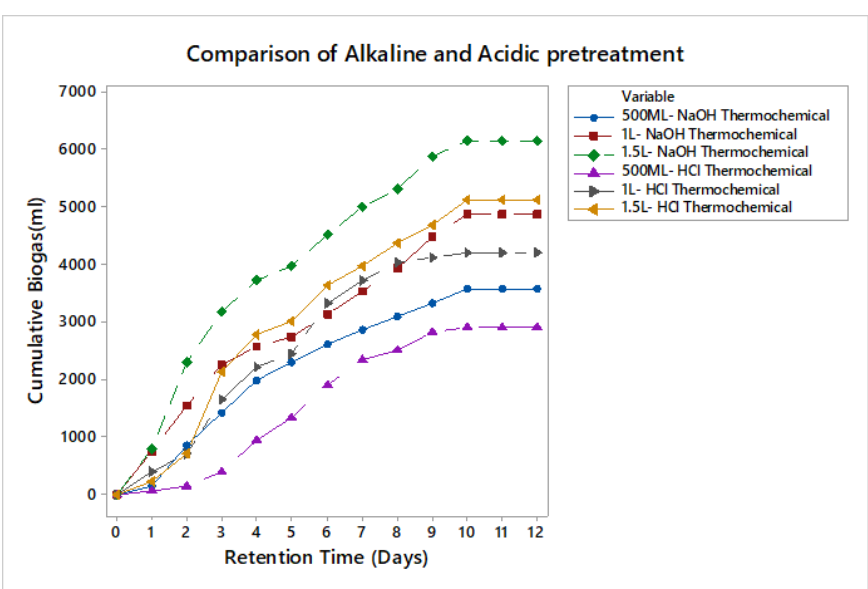

Figure 4 : Cumulative biogas generated from alkaline and acidic pretreated F.V.M.W.

On the other hand, acid pretreatment, mostly diluted acid pretreatments, increases cellulose accessibility by solubilizing hemicellulose. In figure 5 , the cumulative biogas generated from the market wastes pretreated with $\mathrm{NaOH}$ is shown. Low cumulative biogas is recorded in spinach waste at $1069 \mathrm{ml}$, while the highest was recorded in avocado fruit wastes at $4705 \mathrm{ml}$. The high-fat content explains this in avocado $(9.03 \pm 1.36)$ compared to spinach $(0.17 \pm 0.10)$. In general, wastes with high fat, carbohydrates and protein content recorded higher biogas production.

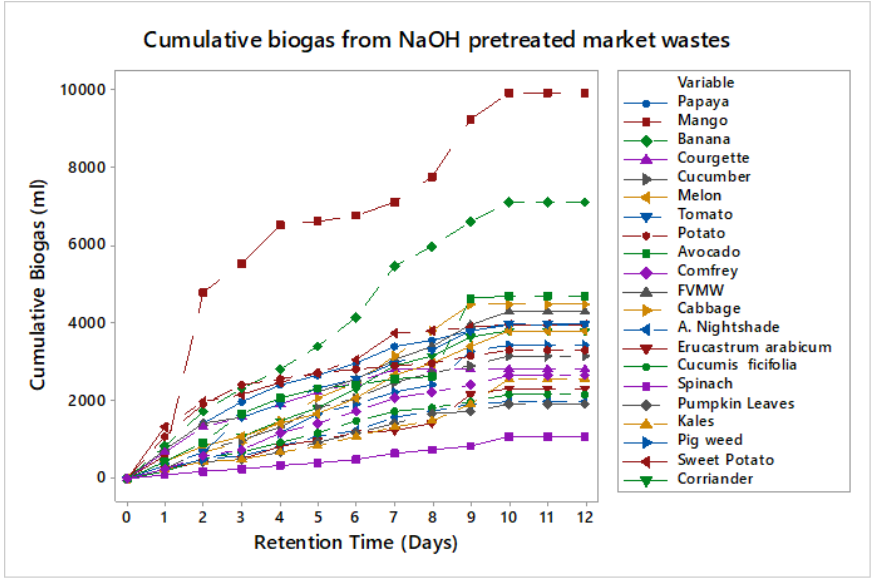

Figure 5 : Biogas generated from $\mathrm{NaOH}$ pretreated market wastes

The influence of the alkali pretreatment in mesophilic biogas production depends on the level of decay of the waste. A $10-20 \%$ increase in biogas production was observed for all the wastes except for avocado, banana, and mango, which recorded more than $40-50 \%$ biogas increment. Owing to their structure and composition, the lignocellulosic materials are hydrolysis resistant. Lignin is also partially solubilized by pretreatment with alkali, enabling cellulose and hemicellulose to be more available. Lime, K.O.H. and $\mathrm{NaOH}$ are the most common alkali employed in pretreatment (Monlau et al., 2013; Bochmann and Montgomery, 2013). The effectiveness of alkaline pretreatment depends on the composition of the biomass as well as the pretreatment conditions. Alkali pretreatment contributes to salt build-up and increased $\mathrm{pH}$ during continuous fermentation. The high concentration of salt and the effects on ammonium-ammonia balance prevent methanisation (Chen et al., 2008). The condition of alkali pretreatment varies depending on the type and composition of biomass used for pretreatment. The most critical parameters affecting the pretreatment of lignocellulosic biomass are the type of alkali, the concentration of alkali, biomass loading, pretreatment temperature, and pretreatment time (Raveendran, Ashok and Parameswaran, 2015).

Acid hydrolysis resulted in almost similar biogas generation levels as alkaline pretreatment. Higher production levels were witnessed in courgette and Erucastrum arabicium at $5490 \mathrm{ml}$ and $5210 \mathrm{ml}$, respectively, as shown in figure 6.

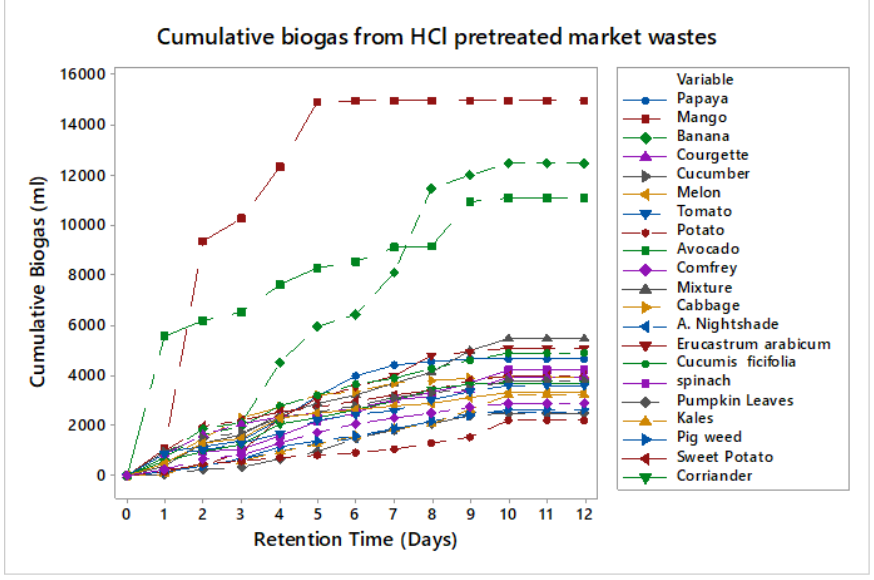

Figure 6 : Biogas generated from $\mathrm{HCl}$ pretreated market wastes 
Sludge disintegration and cell lysis are caused by acid pretreatment, which releases intracellular organics that become more bioavailable and thus improves the rate and efficiency of the digestion method (Eskicioglu et al., 2007). The H-bond, Van der Waals forces and covalent bonds in lignocellulosic matter are disrupted during pretreatment resulting in the breakdown of hemicellulose and cellulose reduction of cellulose (Li et al., 2010). In a study by Devlin et al. (2011), WAS was digested using $\mathrm{HCl}$ at $\mathrm{pH} 2,35^{\circ} \mathrm{C}$ and 12-day H.R.T. resulting in a $14.3 \%$ increment in $\mathrm{CH}_{4}$ production in comparison to untreated WAS. Dilute $\mathrm{H}_{2} \mathrm{SO}_{4}$ pretreatment was used by Taherdanak et al. (2018) to enhance bio-methane production from the wheat plant under mesophilic anaerobic digestion. A maximum methane yield of 15.5 percent higher than that of the untreated wheat plant was obtained at $121 \mathrm{C}$ after pretreatment for 120 minutes.

The influence of alkaline and acidic pretreatment of market wastes on cumulative biogas generation is comparable. Proximate properties, $\mathrm{pH}$ and temperature, are the significant factors that influence biogas production. This is because the waste collected is at the decomposing stage, and therefore, lignin is already disintegrating. However, depending on the nature of the waste and the decay level, pretreatment influence biogas production levels. For example, the cumulative biogas from untreated avocado, mango and banana wastes at mesophilic anaerobic digestion is $300 \mathrm{ml}, 900 \mathrm{ml}$ and $1500 \mathrm{ml}$, respectively. Figure 7 shows that pretreating these wastes with $\mathrm{HCl}$ results in $11088 \mathrm{ml}, 14798 \mathrm{ml}$ and $12476 \mathrm{ml}$ in avocado, mango and banana wastes while pretreating with $\mathrm{NaOH}$ give $4705 \mathrm{ml}, 9922 \mathrm{ml}$ and $7113 \mathrm{ml}$, respectively, as shown in figure 7.

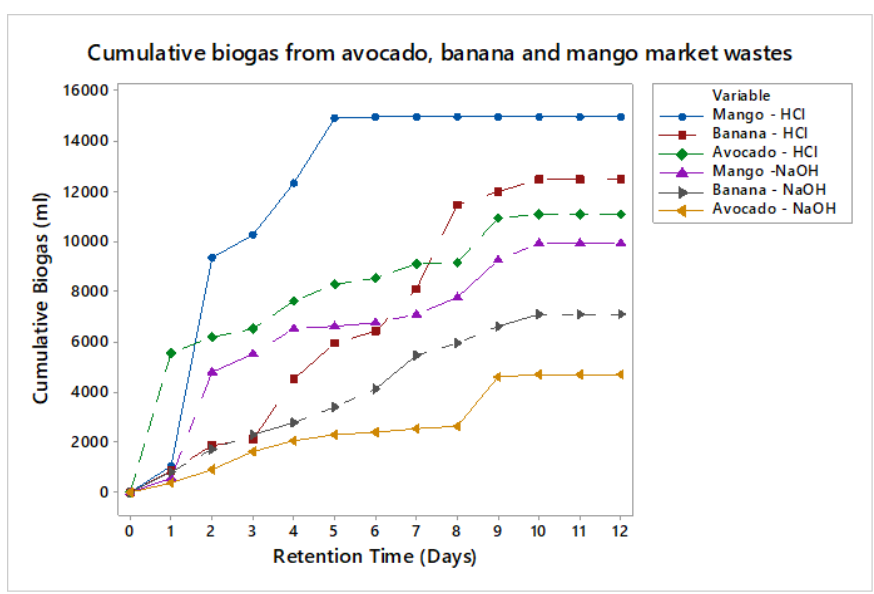

Figure 7 : Biogas generated from $\mathrm{NaOH}$ and $\mathrm{HCl}$ pretreated avocado, mango and banana wastes

The influence of acidic thermochemical pretreatment results in over 30 -fold increment in biogas generation in avocado, 16-fold increment in mango and 8-fold increment in banana. The same is observed with alkaline thermochemical pretreatment with 15-fold, 11-fold and a 5-fold increase in avocado, mango, and banana.

In the large-scale studies, the influence of the amount of substrate, pretreatment chemical and retention time on cumulative biogas generation is shown in figure 8. The highest levels of biogas were generated from wastes treated with $\mathrm{HCl}$ at $34400 \mathrm{ml}$.

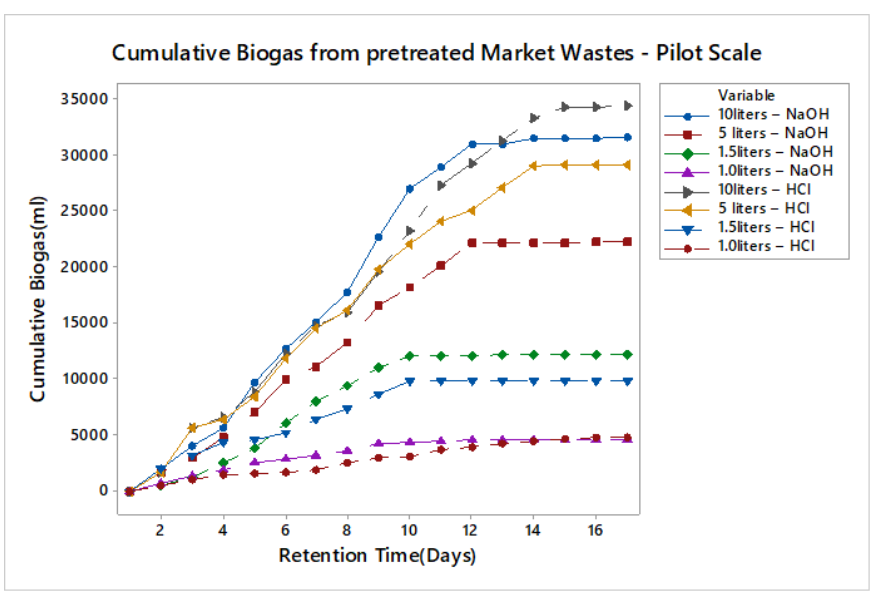

Figure 8 : Cumulative biogas produced from pretreated F.V.M.W. at large scale 


\section{CONCLUSION}

The thermochemical pretreatment gave the best result among three methods, followed by thermal and then chemical pretreatments with cumulative biogas generation increased by $20-57 \%, 17-36 \%$ and $10-33 \%$, respectively. The effectiveness of the thermochemical pretreatment relies heavily on the proximate properties of the wastes. Alkaline pretreated litters produced more biogas on the large-scale compared to acidic pretreated wastes. Therefore, this study recommends thermochemical pretreatment of market wastes before loading into the digester for biogas production.

\section{ACKNOWLEDGMENT}

The authors wish to express their sincere gratitude to the National Research Fund (N.R.F.), grants no. 501000-053 for funding this research work.

\section{REFERENCES}

[1]. Anderson, L. (1972), Energy Potential from Organic Wastes: A Review of the Quantities and Sources. Bureau of Mines Information Circular 8549, U.S. Dept. Interior.

[2]. Bochmann, G. and Montgomery, L.F.R., (2013). Storage and pretreatment of substrates for biogas production. In: The Biogas Handbook: Science, Production and Applications. Elsevier Inc., pp. 85-103

[3]. Carlsson, M., Lagerkvist, A., MorganSagastume, F. (2012). The effects of substrate pretreatment on anaerobic digestion systems: a review. Waste Manag. 32 (9):1634-1650.

[4]. Chen, Y., Ke, Z., and Liang, Y. (2019). "Influence of moisture content of solid-state $\mathrm{NaOH}$ pretreatment and codigestion on methane production in the semi-dry anaerobic digestion of rose stalk," BioRes. 14(2): 42104223.

[5]. Damisa, D., Ameh, J. B. and Umoh, V. J. (2008) Effect of chemical pretreatment of some lignocellulosic wastes on the recovery of cellulase from Aspergillus Niger AH3 mutant, African Journal of Biotechnology, 7(14): 24442450

[6]. Delge' nes J, Penaud V, Torrijos M and Moletta $\mathrm{R}$ (2000) 'Investigations of the changes in anaerobic biodegradability and biotoxicity of an industrial microbial biomass induced by thermochemical pretreatment', Water Science and Technology, 41(3):137-144.

[7]. Devlin D.C, Esteves S.R.R, Dinsdale R.M, Guwy A.J. (2011) The effect of acid pretreatment on the anaerobic digestion and dewatering of waste activated sludge. Bioresource Technology.;102:4076-4082.

[8]. DiStefano T and Ambulkar A (2006) 'Methane production and solids destruction in an anaerobic solid waste reactor due to postreactor caustic and heat treatment', Water Science and Technology, 53(8):33-41.

[9]. Eskicioglu C, Kennedy K.J, Droste R L (2007). Enhancement of batch waste activated sludge digestion by microwave pretreatment. Water Environment Research., 79: 2304-2317.

[10]. Fisgativa, H., Tremier, A., Le Roux, S., Bureau, C., Dabert, P. (2017). Understanding the anaerobic biodegradability of food waste: relationship between the typological, biochemical and microbial characteristics. J. Environ. Manage, 188:95-107.

[11]. Günther B and Lucy F.R. M (2013) Storage and pretreatment of substrates for biogas production, The Biogas Handbook, Woodhead Publishing, Pages 85-103

[12]. Günther Bochmann and Lucy F.R. Montgomery(2013), Storage and pretreatment of substrates for biogas production in The Biogas Handbook, 
[13]. Kamau, J. M., Mbui, D. N., Mwaniki J. M., \& Mwaura, F. B. (2020). Proximate analysis of fruits and vegetables wastes from Nairobi County, Kenya. Research Journal of Food Science and Nutrition, 5(1): 9-15.

[14]. Kim J, Park C, Kim T, Lee M, Kim S, Kim S and Lee J (2003) 'Effects of variouspretreatments for enhanced anaerobic digestion with waste activated sludge', Journal of Bioscience and Bioengineering, 95(3): 271-275.

[15]. Li C, Knierim B, Manisseri C, Arora R, Scheller H.V, Auer M, et al. (2010) Comparison of dilute acid and ionic liquid pretreatment of switch grass: Biomass recalcitrance, delignification and enzymatic saccharification. Bioresource Technology.;101:4900-4906.

[16]. Mancini, G., Papirio, S., Lens, P.N.L., Esposito, G., (2018). Increased biogas production from wheat straw by chemical pretreatments. Renew. Energy 119: 608 - 614.

[17]. Monlau, F.; Aemig, Q.; Barakat, A.; Steyer, J.P.; Carrère, H. (2013) Application of optimized alkaline pretreatment for enhancing the anaerobic digestion of different sunflower stalks varieties, Environ. Technol., 34: 2155-2162

[18]. Noike T, Endo G, Chang J-E, Yaguch, J-I and Matsumoto J-I (1985) 'Characteristics of carbohydrate degradation and the rate-limiting step in anaerobic digestion'. Biotechnology and Bio engineering, 27, (10):1482-1489.

[19]. Peces, M. Astals, S., Mata-Alvarez, J. (2005) Effect of Moisture on Pretreatment Efficiency for Anaerobic Digestion of Lignocellulosic Substrates. Waste Manag., 46:189-196. DOI: 10.1016/j.wasman.2015.08.022.

[20]. Penaud V, Delgenes J, Moletta R (1999) 'Thermo-chemical pretreatment of amicrobial biomass: influence of sodium hydroxide addition on solubilization and anaerobic digestion', Enzyme and Microbial Technology, 25, (3-5):258-263.
[21]. Rafique R, Poulsen T, Nizami A, Asam Z, Murphy J and Kiely G (2010) 'Effect ofthermal, chemical and thermo-chemical pretreatments to enhance methaneproduction', Energy, 35(12):4556-4561.

[22]. Rajan S, Shailey S, Avanish K. T, Shilpi A, Shefali A, Naveen S(2015)Influence of pretreatment processes onto bio-methanation of wheat straw, Journal of Renewable and Sustainable Energy 7, 053109.

[23]. Raveendran S, Ashok P, Parameswaran B (2015), Pretreatment of Biomass, Chapter 4 Alkaline Treatment, Pages 51-60,

[24]. Salemdeeb, R., Vivanco, D.F., Al-Tabbaa, A., Ermgassen, E.K.H.J., (2017). A holistic approach to the environmental evaluation of food waste prevention. Waste Manage, 59:442-450.

[25]. Taherdanak M, Zilouei H, Karimi K (2016). The influence of dilute sulfuric acid pretreatment on biogas production form wheat plant. International Journal of Green Energy. 13(11):1129-1134.

[26]. Tanaka S., Kobayashi T., Kamiyama K.I., Signey Bildan Ma.L.N (1997) Effects of thermochemical pretreatment on the anaerobic digestion of waste activated sludge Water Science and Technology, 35 (8):209-215.

[27]. Xie S, Frost J.P, Lawlor P.G, Wu G. and Zhan X. (2011) Effects of thermo-chemical pretreatment of grass silage on methane production by anaerobic digestion, Bioresource Technology, 102(19):8748 - 8755

[28]. Yang, T.C., Kumaran, J., Amartey, S., Maki, M., Li, X., Lu, F. and Qin, W. (2014) Biofuels and bioproducts produced through microbial conversion of biomass. Bioenergy Research: Advances and Applications, pp.71-93.

[29]. Zhang Q, Tang L, Zhang J, Mao Z and Jiang L (2011) 'Optimization of thermal-dilute sulphuric acid pretreatment for enhancement of methane production from cassava residues', Bioresource Technology, 102 (4):3958-3965. 
[30]. Kong, X., Du, J., Ye, X., Xi, Y., Jin, H., Zhang, M., Guo, D. (2018) Enhanced Methane Production from Wheat Straw with the Assistance of Lignocellulolytic Microbial Consortium TC-5, Bioresour. Technol., 263, 3339.

\section{Cite this article as :}

Kamau J. M, Mbui D. N, Mwaniki J. M, Waswa G. A., "Effect of Thermo-Chemical Pretreatment of Kenyan Market Waste on Mesophillic Biogas Production", International Journal of Scientific Research in Science, Engineering and Technology (IJSRSET), Online ISSN : 2394-4099, Print ISSN : 2395-1990, Volume 8 Issue 3, pp. 22-31, May-June 2021. Available at doi $\quad$ : https://doi.org/10.32628/IJSRSET2182103 Journal URL : https://ijsrset.com/IJSRSET2182103

Table 1: Proximate analysis on wet weight fruit and vegetable wastes

\begin{tabular}{|c|c|c|c|c|c|c|c|c|}
\hline Sample & $\begin{array}{c}\% \\
\text { Moisture }\end{array}$ & $\begin{array}{c}\% \\
\text { Protein }\end{array}$ & $\%$ Fat & $\%$ Ash & $\%$ Fiber & $\%$ Carb. & $\%$ N.F.E. & $\begin{array}{c}\text { Energy } \\
\text { (Kcal/100g) }\end{array}$ \\
\hline Kales & $89.85 \pm 3.63$ & $2.27 \pm 0.12$ & $0.34 \pm 0.17$ & $1.94 \pm 0.05$ & $1.57 \pm 0.12$ & $4.03 \pm 1.00$ & $4.03 \pm 1.11$ & $28.27 \pm 3.97$ \\
\hline Cabbage & $94.87 \pm 2.56$ & $0.83 \pm 0.07$ & $0.05 \pm 0.01$ & $0.49 \pm 0.02$ & $0.54 \pm 0.06$ & $3.22 \pm 0.92$ & $3.22 \pm 0.89$ & $16.64 \pm 4.01$ \\
\hline $\begin{array}{l}\text { Pumkin } \\
\text { Leaves }\end{array}$ & $90.78 \pm 1.55$ & $2.27 \pm 0.36$ & $0.18 \pm 0.08$ & $2.06 \pm 0.12$ & $0.94 \pm 013$ & $3.77 \pm 0.87$ & $3.77 \pm 0.99$ & $25.78 \pm 2.88$ \\
\hline $\begin{array}{l}\text { Cucumis } \\
\text { ficifolia }\end{array}$ & $86.62 \pm 2.98$ & $3.49 \pm 0.72$ & $0.33 \pm 0.11$ & $2.34 \pm 0.05$ & $1.48 \pm 0.52$ & $5.74 \pm 1.02$ & $5.74 \pm 1.04$ & \begin{tabular}{|l|}
$39.89 \pm 2.37$ \\
\end{tabular} \\
\hline Pigweed & $88.64 \pm 2.00$ & $2.61 \pm 0.55$ & $0.21 \pm 0.7$ & $2.86 \pm 0.01$ & $2.06 \pm 0.78$ & $3.62 \pm 0.85$ & $3.62 \pm 0.88$ & $26.81 \pm 7.00$ \\
\hline $\begin{array}{c}\text { Erucastrum } \\
\text { arabicum }\end{array}$ & $89.37 \pm 2.11$ & $2.82 \pm 0.89$ & $0.19 \pm 0.02$ & $1.99 \pm 0.07$ & $1.68 \pm 0.23$ & $3.95 \pm 0.47$ & $3.95 \pm 0.03$ & $28.79 \pm 1.99$ \\
\hline Coriander & $92.12 \pm 4.47$ & $2.6 \pm 0.23$ & $0.09 \pm 0.03$ & $1.91 \pm 0.05$ & $1.12 \pm 0.09$ & $2.16 \pm 0.36$ & $2.16 \pm 0.08$ & $19.85 \pm 1.97$ \\
\hline A.Nightshade & $88.15 \pm 1.99$ & $2.68 \pm 0.36$ & $0.26 \pm 0.10$ & $1.97 \pm 0.03$ & $2.73 \pm 0.11$ & $4.12 \pm 0.56$ & $4.21 \pm 1.10$ & $29.91 \pm 1.13$ \\
\hline Spinach & $93.27 \pm 2.33$ & $1.53 \pm 0.09$ & $0.17 \pm 0.10$ & $1.73 \pm 0.03$ & $0.92 \pm 0.12$ & $2.38 \pm 0.54$ & $2.38 \pm 0.19$ & $17.17 \pm 2.00$ \\
\hline Comfrey & $85.04 \pm 3.56$ & $3.24 \pm 0.78$ & $0.29 \pm 0.12$ & $3.46 \pm 0.14$ & $2.07 \pm 0.23$ & $5.9 \pm 1.11$ & $5.90 \pm 1.88$ & $39.17 \pm 2.22$ \\
\hline Tomato & $95.16 \pm 4.00$ & $0.57 \pm 0.01$ & $0.12 \pm 0.01$ & $0.46 \pm 0.01$ & $0.76 \pm 0.01$ & $2.93 \pm 0.09$ & $15.08 \pm 1.11$ & $2.93 \pm 0.05$ \\
\hline Potato & $83.78 \pm 4.23$ & $1.41 \pm 0.87$ & $0.54 \pm 0.21$ & $0.81 \pm 0.02$ & $1.74 \pm 0.14$ & $11.72 \pm 1.00$ & $57.38 \pm 6.88$ & $11.72 \pm 0.99$ \\
\hline Sweet Potato & $62.05 \pm 2.99$ & $1.67 \pm 0.09$ & $1.54 \pm 0.14$ & $1.06 \pm 0.05$ & $1.51 \pm 0.23$ & $32.17 \pm 2.31$ & $149.22 \pm 20.01$ & $32.17 \pm 2.44$ \\
\hline Pawpaw & $89.22 \pm 2.12$ & $0.68 \pm 0.03$ & $0.34 \pm 0.07$ & $0.5 \pm 0.04$ & $1.31 \pm 0.45$ & $7.95 \pm 0.98$ & $37.58 \pm 5.83$ & $7.95 \pm 1.77$ \\
\hline Banana & $74.3 \pm 2.10$ & $3.05 \pm 0.12$ & $0.5 \pm 0.07$ & $1.67 \pm 0.05$ & $1.24 \pm 0.14$ & $19.24 \pm 1.00$ & $93.66 \pm 19.34$ & $19.24 \pm 2.00$ \\
\hline Avocado & $82.83 \pm 3.00$ & $1.32 \pm 0.14$ & $9.03 \pm 1.36$ & $0.84 \pm 0.02$ & $2.61 \pm 0.98$ & $3.37 \pm 0.55$ & $100.03 \pm 12.90$ & $3.37 \pm 1.11$ \\
\hline Courgette & $95.34 \pm 2.00$ & $1.06 \pm 0.54$ & $0.25 \pm 0.08$ & $0.72 \pm 0.03$ & $0.69 \pm 0.10$ & $1.99 \pm 0.12$ & $14.46 \pm 1.69$ & $1.94 \pm 0.11$ \\
\hline Cucumber & $95.86 \pm 2.04$ & $0.52 \pm 0.08$ & $0.21 \pm 0.03$ & $0.46 \pm 0.04$ & $0.78 \pm 0.11$ & $2.17 \pm 0.34$ & $12.65 \pm 2.17$ & $2.17 \pm 0.33$ \\
\hline Mango & $86.82 \pm 3.89$ & $0.87 \pm 0.07$ & $0.68 \pm 0.08$ & $0.44 \pm 0.02$ & $1.28 \pm 0.21$ & $9.91 \pm 1.00$ & $49.24 \pm 2.88$ & $9.91 \pm 1.00$ \\
\hline Water Melon & $92.85 \pm 4.55$ & $0.90 \pm 0.09$ & $0.33 \pm 0.04$ & $0.74 \pm 0.04$ & $0.76 \pm 0.09$ & $4.42 \pm 0.88$ & $24.18 \pm 2.45$ & $4.42 \pm 0.78$ \\
\hline
\end{tabular}


Kamau J. M et al Int J Sci Res Sci Eng Technol, May-June-2021, 8 (3) : 22-31

Table 2: Physical analysis properties of various market wastes

\begin{tabular}{|c|c|c|c|c|c|c|c|c|c|c|c|c|}
\hline \multirow[t]{2}{*}{ SAMPLE } & \multicolumn{2}{|c|}{ \% Moisture } & \multicolumn{2}{|c|}{ Total Solids } & \multicolumn{2}{|c|}{ \% A.S.H. } & \multicolumn{2}{|c|}{$\begin{array}{c}\text { \%Mineral } \\
\text { Matter }\end{array}$} & \multicolumn{2}{|c|}{$\begin{array}{c}\text { \% Volatile } \\
\text { Matter }\end{array}$} & \multicolumn{2}{|c|}{$\begin{array}{c}\text { \% Fixed } \\
\text { Solids }\end{array}$} \\
\hline & WET & DRY & WET & DRY & WET & DRY & WET & DRY & WET & DRY & WET & DRY \\
\hline Kales & 89.85 & 10.53 & 10.15 & 89.47 & 1.94 & 18.45 & 2.134 & 20.295 & 8.21 & 71.02 & 6.27 & 52.57 \\
\hline Cabbage & 94.87 & 5.13 & 5.13 & 94.87 & 0.49 & 9.7 & 0.539 & 10.67 & 4.64 & 85.17 & 4.15 & 75.47 \\
\hline $\begin{array}{l}\text { Pumkin } \\
\text { Leaves }\end{array}$ & 90.78 & 8.77 & 9.22 & 91.23 & 2.06 & 23.86 & 2.266 & 26.246 & 7.16 & 67.37 & 5.1 & 43.51 \\
\hline $\begin{array}{l}\text { Cucumis } \\
\text { ficifolia }\end{array}$ & 86.62 & 13.38 & 13.38 & 86.62 & 2.34 & 17.52 & 2.574 & 19.272 & 11.04 & 69.1 & 8.7 & 51.58 \\
\hline Pigweed & 88.64 & .36 & 11.36 & 8.64 & 2.86 & 25.26 & 146 & 7.786 & 8.5 & 63.38 & 5.64 & 38.12 \\
\hline $\begin{array}{c}\text { Erucastrum } \\
\text { arabicum }\end{array}$ & 89.37 & 10.63 & 10.63 & 89.37 & 1.99 & 18.76 & 2.189 & 20.636 & 8.64 & 70.61 & 6.65 & 51.85 \\
\hline Coriander & 92.12 & 7.88 & 7.88 & 92.12 & 1.91 & 24.3 & 2.101 & 6.73 & 5.97 & 67.82 & 4.06 & 43.52 \\
\hline $\begin{array}{c}\text { A. } \\
\text { Nightshade }\end{array}$ & 88.15 & 11.85 & 11.85 & 88.15 & 1.97 & 16.67 & 2.167 & 18.337 & 9.88 & 71.48 & 7.91 & 54.81 \\
\hline Spinach & 93.27 & 6.73 & 6.73 & 93.27 & 1.73 & 25.67 & 1.903 & 28.237 & 5.00 & 67.6 & 3.27 & 41.93 \\
\hline Comfrey & 85.04 & 14.96 & 14.96 & 85.04 & 3.46 & 23.13 & 3.806 & 25.443 & 11.5 & 61.91 & 8.04 & 38.78 \\
\hline Tomato & 95.16 & 4.84 & 4.84 & 95.16 & 0.46 & 9.53 & 0.506 & 10.483 & 4.38 & 85.63 & 3.92 & 76.1 \\
\hline Potato & 83.78 & 16.21 & 16.22 & 83.79 & 0.81 & 5.02 & 0.891 & 5.522 & 15.41 & 78.77 & 14.6 & 73.75 \\
\hline $\begin{array}{l}\text { Sweet } \\
\text { Potato }\end{array}$ & 62.05 & 37.94 & 37.95 & 62.06 & 1.06 & 2.81 & 1.166 & 3.091 & 36.89 & 59.25 & 35.83 & 56.44 \\
\hline Pawpaw & 89.22 & 10.78 & 10.78 & 89.22 & 0.50 & 4.65 & 0.55 & 5.115 & 10.28 & 84.57 & 9.78 & 79.92 \\
\hline Banana & 74.3 & 25.70 & 25.70 & 74.30 & 1.67 & 6.53 & 1.837 & 7.183 & 24.03 & 67.77 & 22.36 & 61.24 \\
\hline Avocado & 82.83 & 17.17 & 17.17 & 82.83 & 0.84 & 4.92 & 0.924 & 5.412 & 16.33 & 77.91 & 15.49 & 72.99 \\
\hline Courgette & 95.34 & 4.65 & 4.66 & 95.35 & 0.72 & 15.58 & 0.792 & 17.138 & 3.94 & 79.77 & 3.22 & 64.19 \\
\hline Cucumber & 95.86 & 4.14 & 4.14 & 95.86 & 0.46 & 11.14 & 0.506 & 12.254 & 3.68 & 84.72 & 3.22 & 73.58 \\
\hline Mango & 86.82 & 13.18 & 13.18 & 86.82 & 0.44 & 3.33 & 0.484 & 3.663 & 12.74 & 83.49 & 12.3 & 80.16 \\
\hline $\begin{array}{l}\text { Water } \\
\text { Melon }\end{array}$ & 92.85 & 7.14 & 7.15 & 92.86 & 0.74 & 10.49 & 0.814 & 11.539 & 6.41 & 82.37 & 5.67 & 71.88 \\
\hline
\end{tabular}

